\title{
Genetic mechanism and development of the unsteady Sarvak play of the Azadegan oil field, southwest of Iran
}

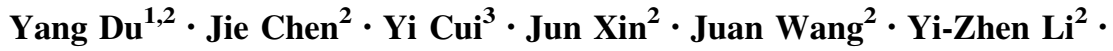 \\ $\mathrm{Xiao} \mathrm{Fu}^{2}$
}

Received: 18 July 2014/Published online: 23 January 2016

(c) The Author(s) 2016. This article is published with open access at Springerlink.com

\begin{abstract}
The upper Cretaceous Sarvak reservoir in the Azadegan oil field of southwest Iran has its oil-water contact nearly horizontal from the north to the center and dips steeply from the center to the south. The purpose of this paper is to interpret this abnormal reservoir feature by examining the accumulation elements, characteristics, and evolution based on the 3D seismic, coring, and well logging data. Generally, in the field, the Sarvak reservoir is massive and vertically heterogeneous, and impermeable interlayers are rare. The distribution of petrophysical properties is mainly dominated by the depositional paleogeomorphology and degrades from north to south laterally. The source is the lower Cretaceous Kazhdumi Formation of the eastern Dezful sag, and the seal is the muddy dense limestone of the Cenozoic Gurpi and Pebdeh Formations. Combined with the trap evolution, the accumulation evolution can be summarized as follows: the Sarvak play became a paleo-anticlinal trap in the Alpine tectonic activity after the late Cretaceous (96 Ma) and then was relatively peaceful in the later long geologic period. The Kazhdumi Formation entered in the oil window at the early Miocene (12-10 Ma) and charged the Sarvak bed, thus forming the paleo-reservoir. Impacted by the Zagros
\end{abstract}

Yang Du

157762166@qq.com

1 School of Geoscience and Technology, Southwest Petroleum University, Chengdu 610500, Sichuan, China

2 Geology and Exploration Research Institute, CNPC Chuanqing Drilling Engineering Company Limited, Chengdu 610051, Sichuan, China

3 Iraq Branch Company of CNODC, CNPC, Dubai 500486, United Arab Emirates

Edited by Jie Hao
Orogeny, the paleo-reservoir trap experienced a strong secondary deformation in the late Pliocene (4 Ma), which shows as the paleo-trap shrank dramatically and the prelow southern area uplifted and formed a new secondary anticline trap, hence evolving to the current two structural highs with the south point (secondary trap) higher than the north (paleo-trap). The trap deformation broke the paleoreservoir kinetic equilibrium and caused the secondary reservoir adjustment. The upper seal prevented vertical oil dissipation, and thus, the migration is mainly in interior Sarvak bed from northern paleo-reservoir to the southern secondary trap. The strong reservoir heterogeneity and the degradation trend of reservoir properties along migration path (north to south) made the reservoir readjustment extremely slow, plus the short and insufficient re-balance time, making the Sarvak form an "unsteady reservoir" which is still in the readjustment process and has not reached a new balance state. The current abnormal oilwater contact versus the trap evolutionary trend indicates the secondary readjustment is still in its early stage and has only impacted part of paleo-reservoir. Consequently, not all of the reservoir is dominated by the current structure, and some parts still stay at the paleo-reservoir form. From the overview above, we suggest the following for the future development: In the northern structural high, the field development should be focused on the original paleoreservoir zone. In the southern structural high, compared with the secondary reservoir of the Sarvak with the tilted oil-water contact and huge geologic uncertainty, the lower sandstone reservoirs are more reliable and could be developed first, and then the deployment optimized of the upper Sarvak after obtaining sufficient geological data. By the hints of the similar reservoir characteristics and tectonic inheritance with Sarvak, the lower Cretaceous Fahliyan 
carbonate reservoir is also proved to be an unsteady reservoir with a tilted oil-water contact.

Keywords Iran · Azadegan oil field · Sarvak - Oil-water contact - Accumulation elements - Accumulation evolution · Unsteady reservoir · Development suggestion

\section{Introduction}

Azadegan oil field, which lies adjacent to the Iran-Iraq border area of Khuzestan Province in the southwest of Iran, is currently the largest untapped oil field in the world (Liu et al. 2013a; Du et al. 2015a, b) (Fig. 1). Four Cretaceous reservoirs have been found: Sarvak, Kazhdumi (Burgan sandstone), Gadwan (Zubair sandstone), and Fahliyan (Fig. 2). The Sarvak is the main development zone, which accounts for $91.8 \%$ of the total reserves. Preliminary exploration proves that the oil-water contact (OWC) of Sarvak is nearly horizontal in the north-central zone of the field but tilts steeply up from the center to the south along the major axis of the structure, and the height difference can reach over $300 \mathrm{~m}$ according to the drilling (Fig. 3). Additionally, this is not the only case, and neighboring oil fields show similar phenomenon as well. For example (oil field locations below are shown in Fig. 1), the tilted OWC and the $150 \mathrm{~m}$ height difference were discovered in the Sarvak of the eastern Yadavaran oil field (Xu et al. 2010), while the OWC of the upper Cretaceous Sarvak, Ilam reservoir in the eastern Ab-e Teymur, Mansuri, Ahwaz fields tilts from SW to NE. The different OWCs of the Mishrif (upper Sarvak) reservoir which are 2710, 2750, and $2680 \mathrm{~m}$ deep, respectively, were proven in three wells of the western Iraqi Majnoon field. The lower part of the upper Cretaceous Yamama reservoir also has an OWC with a height difference of nearly $150 \mathrm{~m}$ and a tilt angle of $3^{\circ}$. The depth of the oil column in the upper Cretaceous Yamama reservoir of the Umr Nahr field in the west is close to $200 \mathrm{~m}$. The Mishrif of Western Missan field is also a tilted one, and the height difference is $100 \mathrm{~m}$. A good

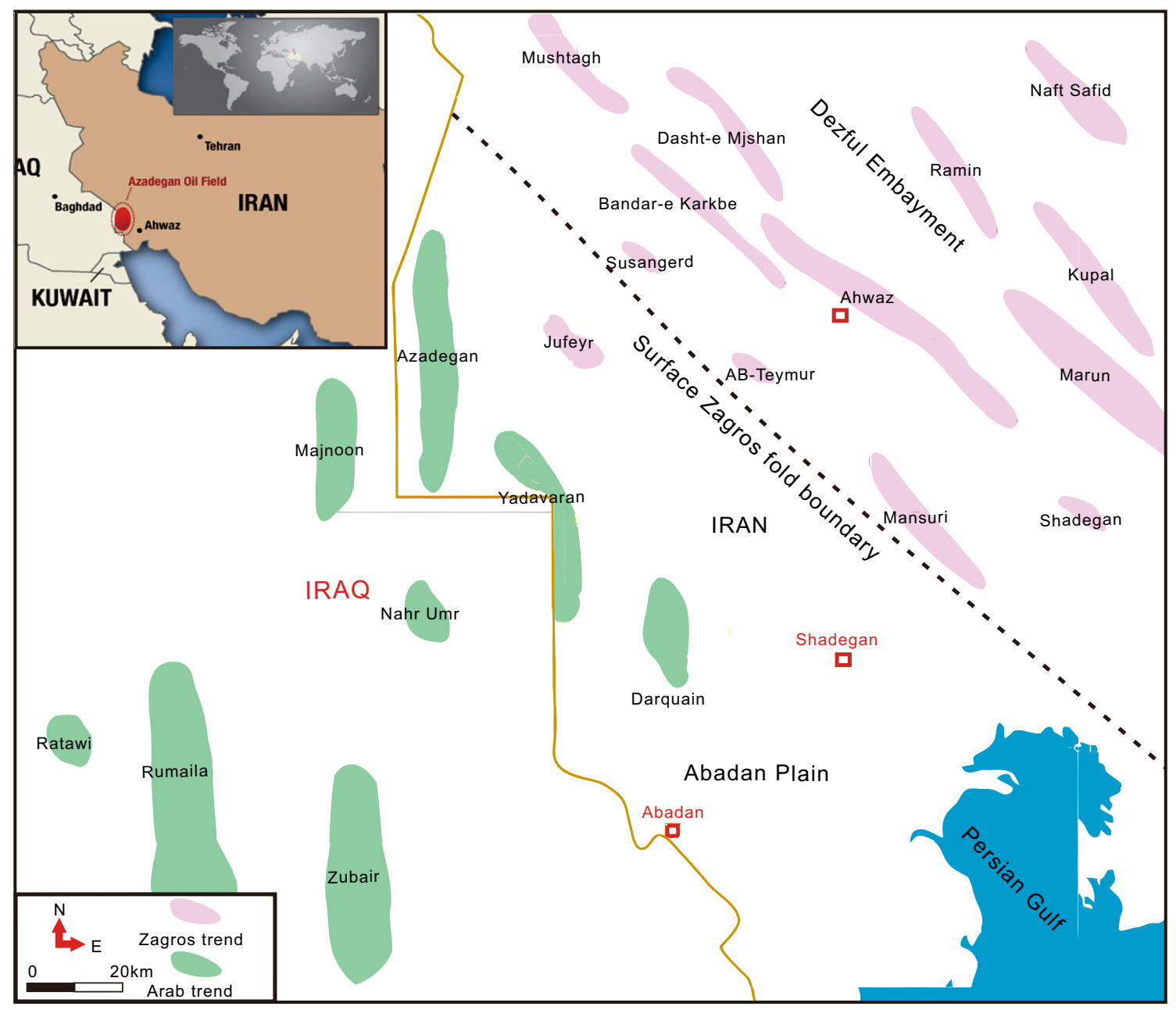

Fig. 1 Regional location map of the Azadegan oil field in southwest Iran 


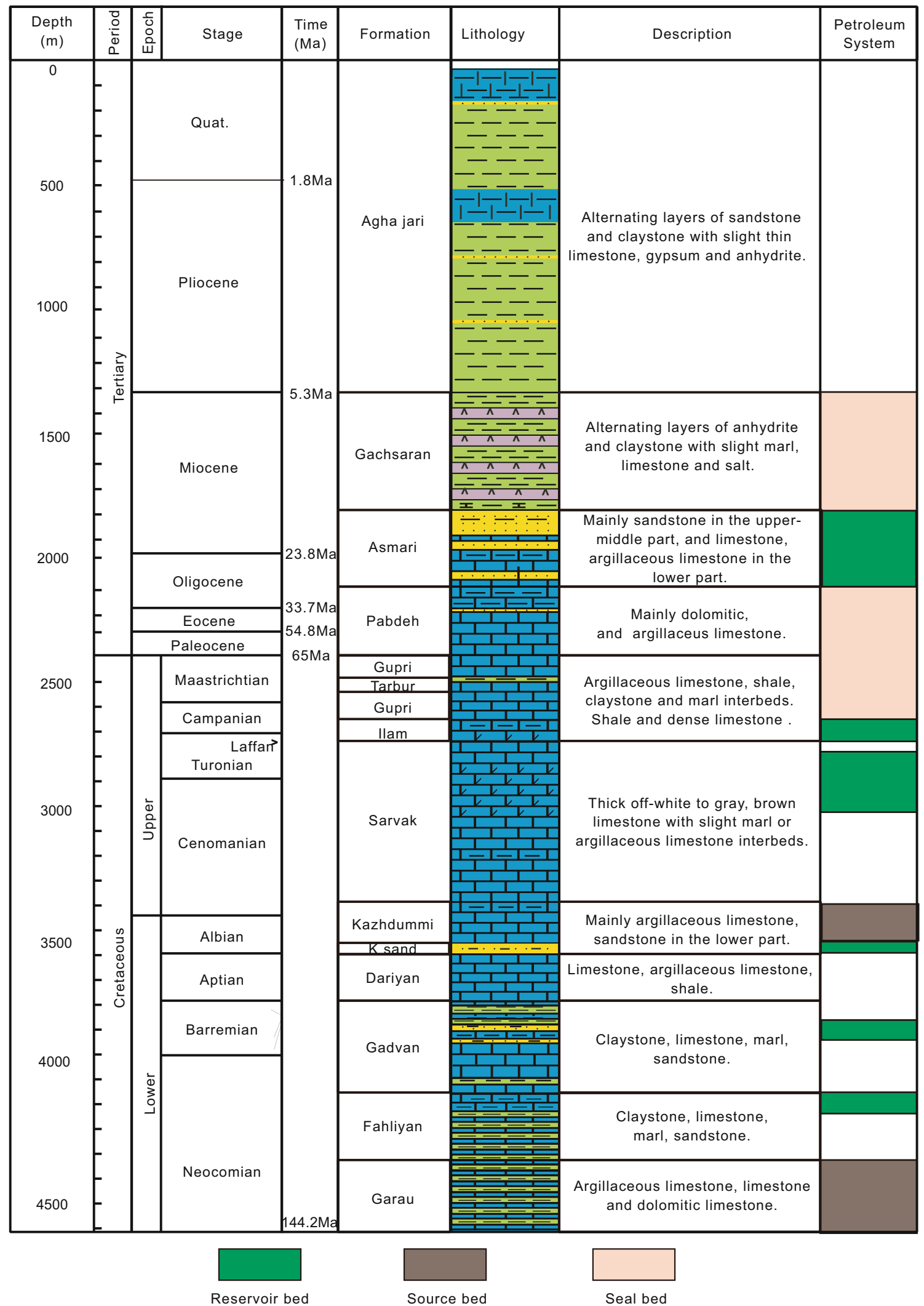

Fig. 2 The stratigraphic column section of the Azadegan oil field in southwest Iran 


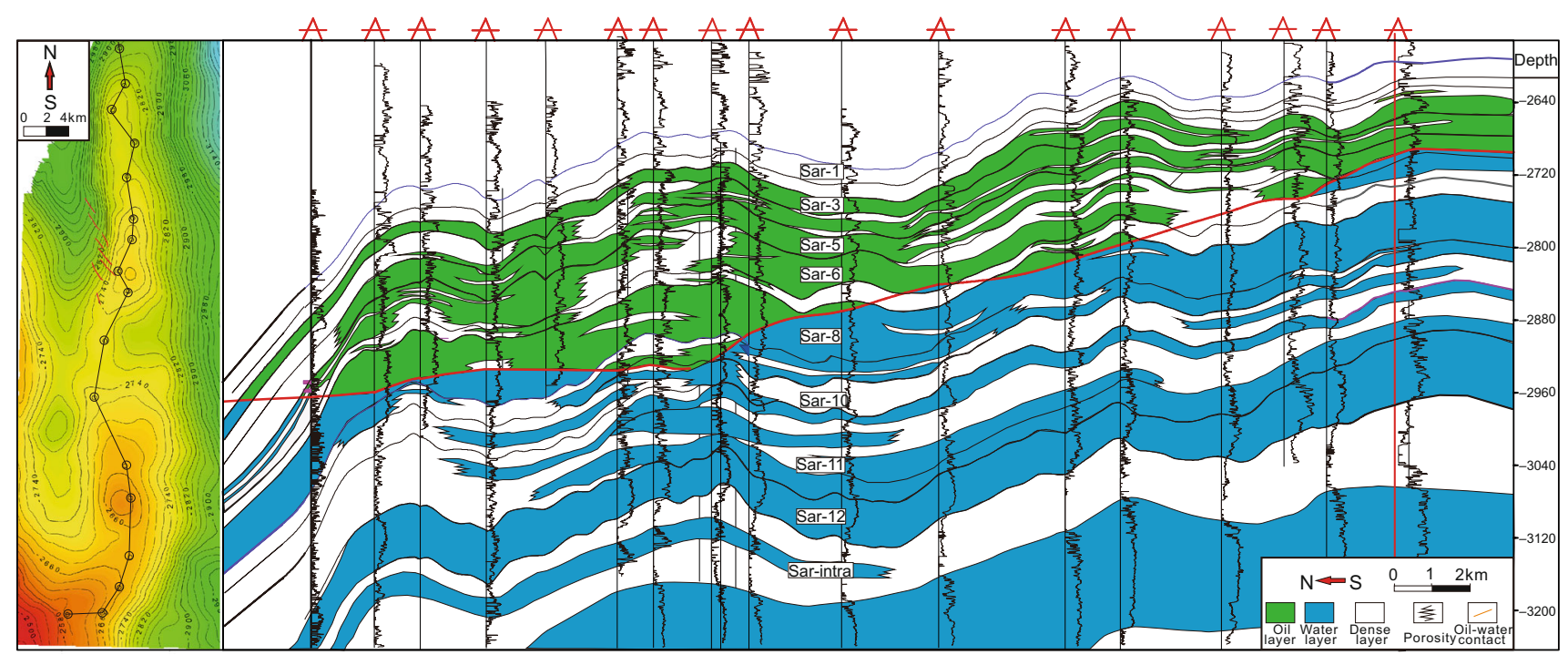

Fig. 3 Reservoir section of the upper Cretaceous Sarvak Formation of the Azadegan oil field (N-S), Iran

knowledge of these abnormal reservoir characteristics and the genesis of the tilted OWC is closely related to the reserve calculations, well spacing, well pattern, and well type, with great significance for field development.

Currently, there is no certain conclusion on the cause of such phenomenon. Some scholars once explained the genesis of the irregular OWC and built accumulation models such as the "differential entrapment" and "leak differential entrapment" (Gussow 1954; Schowalter 1979). However, it is hard to use them to interpret the Azadegan case. We have analyzed and confirmed that faults, hydrodynamics, and reservoir heterogeneity are not the causes, and propose the very late trap deformation by the Zagros orogeny as the main reason for the tilted OWC in Azadegan (Du et al. 2015a). Based on the previous findings, this paper uses the new geological data to describe the accumulation factors including the reservoir, source, and seal, and reconstructs the field paleo-structure and trap evolution history. By analyzing the relationship between the tectonic evolution and reservoir accumulation, the aim is to clarify the genetic mechanism of the unsteady reservoir and then make suggestions for the field development.

\section{Tectonic features and evolution}

\subsection{Tectonic features}

Tectonically, Azadegan oil field is situated in the southwest of the Zagros overthrust fault zone and in the transition zone between the Zagros foreland basin and Arabian platform (Soleimani 2013). Two different types of traps with different forming mechanisms are confirmed here: One type is called the Zagros Trend, located in the foothill zone (Zagros folded zone) with an NW-SE strike, and with similar trends as the anticlinal structure elongated in the Zagros Mountain range. The Miocene Asmari Formation, which is dominantly limestone and partially sandstone, is the main reservoir of the Zagros Trend oil fields (Wang et al. 2011; Zhang et al. 2012; McQuillan 1973, 1974; Bordenave and Hegre 2005). The other type, known as the Arabian Trend-uplifting caused by basement fault "resurrection" and salt flow, widely distributed in a number of oil fields which are located in southeast of Iraq, Kuwait, and northeast of Saudi Arabia, with N-S trending anticlinal structures. In this type of oil field, the reservoirs are mainly Cretaceous Formations, i.e., Ilam, Sarvak in Iran and Mishrif, Rumalia in Iraq (Alsharhan 1995; Alsharhan and Nairn 1997; Beydoun 1991; Sadooni and Aqrawi 2000; Sadooni 2005; Bordenave and Hegre 2005). As shown in Fig. 1, Majnoon, NahrUmr, West Qurna, Rumaila, and Zubair oil fields in Iraq are classified as the Arabian Trend, whereas the oil fields of the Ahwaz area in the east of the Azadegan are identified as the Zagros Trend.

It is understood that the Azadegan field is a huge longaxis N-S trend anticline of the Arabian Trend. The formation is continuous without any huge strike fault (Fig. 4a). Two domes are situated in the north and south, respectively, and are connected by the middle saddle area. Related to the dome elevation, the uplift degree of the southern dome is higher than that of the northern one (Fig. 4b). The northern structure is an N-S trend small-size anticline with steep limbs. The southern structure is in the $\mathrm{N}-\mathrm{S}$ trend with larger oil field area and it extends southwestward into Iraq. 


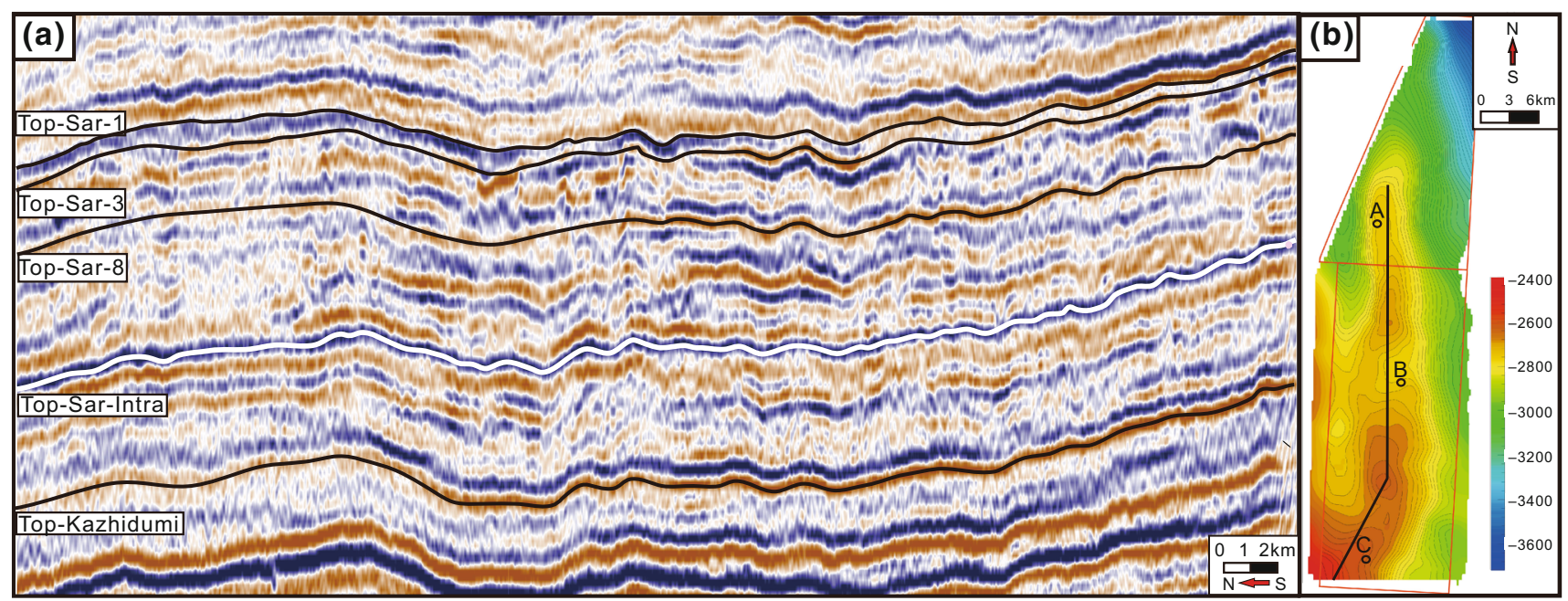

Fig. 4 a The seismic cross section of Sarvak along the structural crest (black line in (b)), b the structural map of the Sarvak top surface

\subsection{Trap evolution}

The Azadegan oil field is located in a part of the Arabian platform. During most of its geological history, it was in a stable subsidence process except for a short period of traceable regional instability in the upper Cretaceous Turonian Stage (Murris 1980; Berberian and King 1981; Koop and Kholief 1982; Alsharhan and Nairn 1997; Alavi 2004). Consequently, in this study, the seismic flattening technique is used to reconstruct the structural trap evolution of Azadegan. According to the previous findings of regional tectonic activities and deposition time of the flattened formations, the genesis and stages of the trap evolution are analyzed and determined.

The available data show that the Arabian Platform was a part of the Gondwana super-continent during the Precambrian and early Paleozoic (Stöcklin 1968; Berberian and King 1981). By the end of the Precambrian, the Arabian Plate was characterized by the extension of a discontinuous subsiding basin with very thick evaporite deposition. The Hercynian Orogeny in the late Paleozoic had caused the formation of the N-S trending horsts and grabens (Stöcklin 1968; Murris 1980). From the late Carboniferous to the early Permian, the northeastern margin of intra-continental rifting and seafloor spreading along the Zagros belt formed the new Tethys Ocean and led to the separation of the Iranian and Arabian plates (Alavi 1994; Glennie 2000; Sherkati and Letouzeh 2004; Sepehr and Cosgrove 2004). After entering the middle of the Cretaceous, with the Arabian plate drifting to the north, the plate moved from the passive continental margin into the active continental margin development stage (Alavi 2004) and experienced two periods of tectonic activity.

The first period is the Alpine tectonic activity of the upper Cretaceous. From early to middle Cretaceous, the
Arabian plate subduction caused tectonic movement, resulting in the regional sedimentary evolution with active tectonic extrusion and Neo-Tethys contraction. This tectonic change turned the area into an active and compressional tectonic setting from the Cenomanian of the Cretaceous, which caused a readjustment of the fault system to the N-S strike during the early Hercynian and brought an increment in salt movement, such as salt plugs, swells, ridges, and relevant domes of the N-S Arabian trend. Regionally, these structures are abundant in the Persian Gulf, Saudi Arabia, Kuwait, southeast Iraq, and southwest Iran (Murris 1980; Koop and Kholief 1982; Glennie 2000; Sherkati and Letouzeh 2004). In the Azadegan field, the Sarvak occurs as a result of carbonate shelf deposition in the mid-Cretaceous (Murris 1980; Alsharhan and Nairn 1997; Bordenave and Hegre 2005). In the early Paleocene (65 Ma, Fig. 5a), a wide and gentle paleo-fold has emerged in the current northern field area. Towards the early Miocene (20 Ma, Fig. 5b), it had evolved into the N-S strike anticline by the impact of plate extrusion. The paleo-anticline was higher in the north and lower in the south, which is in contrary to the current structural feature of south higher than north.

The second period is the Zagros orogeny of the early Miocene. Due to the second collision of the Arabian Plate and central Iranian Plate in the Miocene, the Neo-Tethys Ocean closed and the Zagros Fold Belt formed. This tectonic activity began approximately 20-16 Ma ago, from the Zagros Mountains piedmont region to the Dezful Depression where the oil field is located, which contributed to the typical Zagros anticlines manifested in the form of large-amplitude asymmetric whaleback-shaped mountains (Colman 1978; Berberian and King 1981; Sherkati and Letouzeh 2004; Alavi 1982, 1994, 2004). The extension of this NW-SE strike fold, named the Zagros Trend, has been 


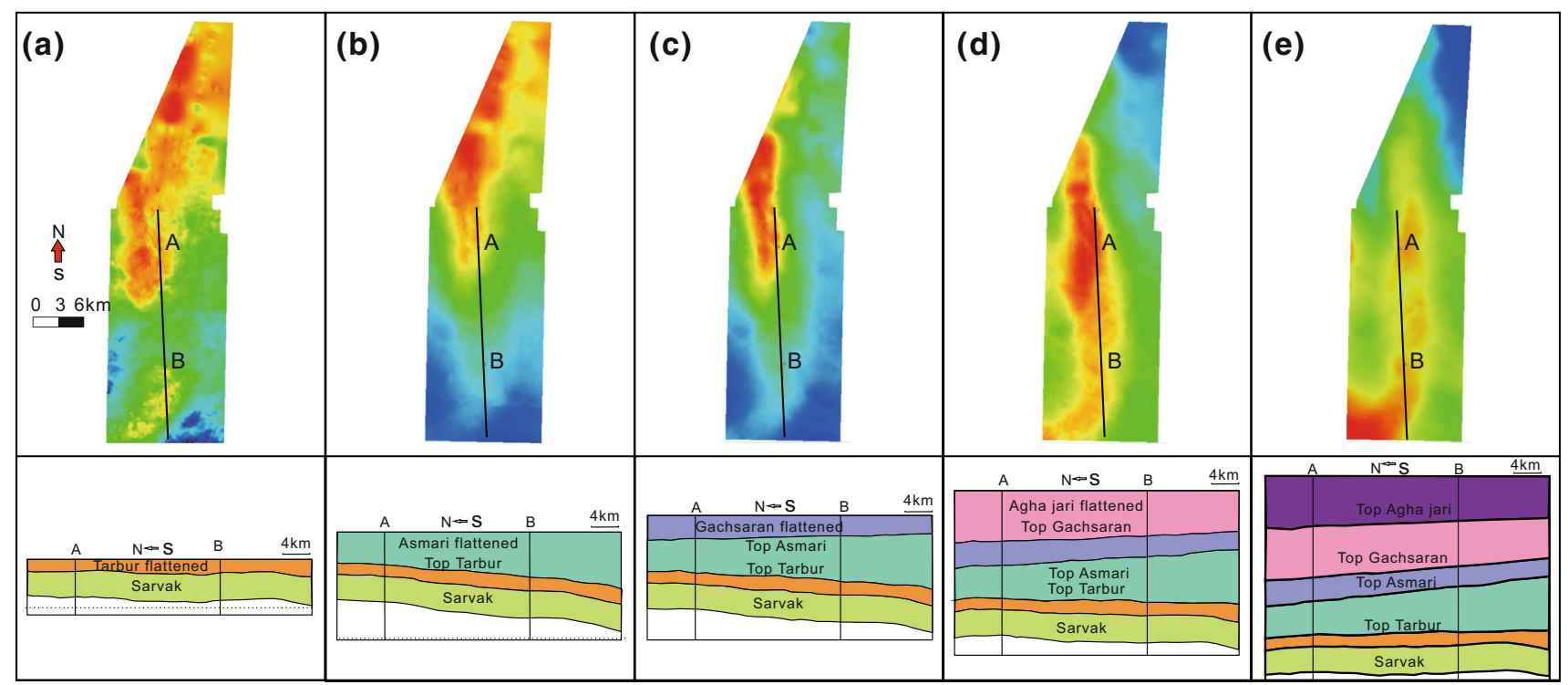

Fig. 5 Tectonic evolution section of Sarvak Formation (light color represents the high structure, and the dark color represents the low structure) and the depositional formations in different geological stages which are depicted by the flattened seismic balanced section crossing the line of the A and B wells. a Paleo-structure of the Sarvak in the Paleocene (flattened by the top of the Tarbur Formation in the Paleocene, 65 Ma); $\mathbf{b}$ Paleostructure of the Sarvak in the Early Miocene (flattened by the top of the Asmari Formation in the middle Miocene, 20 Ma); c Paleo-structure of the Sarvak in the Late Miocene (flattened by the top of the Gachsaran Formation in the Late Miocene, 6 Ma); d Paleo-structure of the Sarvak in the Pliocene (flattened by the top of the Aghajari Formation in the Pliocene, $2 \mathrm{Ma}$ ); e Current structure of the top of the Sarvak Formation

formed continuously throughout time from NE to SW and is limited by the Iranian shoreline and Iran-Iraq border in the northwest. Besides this, due to the extrusion stress decreasing, the folding amplitude as well as the deformation intensity decreased progressively following the same trend (Hessami et al. 2001; Alavi 2004). The borderline along the low-amplitude Zagros trend traps, such as Ab-e Teymur and Mansuri (formed during 5-4 Ma) in the east of the Azadegan oil field, is deemed as the boundary of the surface Zagros folded zone (Hessami et al. 2001; Bordenave and Hegre 2005). This means that the effect of the Zagros Trend is hardly observed on the surface outside the line, where the buried structure zone exists (Fig. 1). In the buried zone, it is hard to observe the fold on the surface, but the subsurface formation is still tectonically active, and the structural activity is trending towards the southwest continuously. Under the control of early basement faults like the Najad fault system, a new subsurface Zagros fold formed and some early folds like the Arabian fold were subdued to secondary deformation (Sepehr and Cosgrove 2004). Up to now, it is an ongoing tectonic evolution trending to the southwest.

For the Azadegan field, since the Zagros orogeny took place, the trap deformation accelerated significantly shown as the trap scale shrinking dramatically and the limbs becoming steeper. Until the late Miocene (6 Ma, Fig. 5c), the fold have evolved from a wide and gentle anticline into a long-narrow one. Before about $3 \mathrm{Ma}$ (the latest surface Zagros fold formed at nearly $4 \mathrm{Ma}$ ), the plate nappe stress reached the Azadegan oil field and led to the deep basement fault being reactivated (Sepehr and Cosgrove 2004), causing the trap to experience strong secondary deformation. The northern paleo-trap was squeezed continuously and evolved into the northern high of the field nowadays. The southern paleo-low part behaves as a "teeterboard," sharply uplifted and formed a new secondary trap. The top surface of the Pliocene Aghajari Formation which was deposited before $2 \mathrm{Ma}$ is flattened (Fig. 5d), and it can be seen that the northern paleo-trap narrowed sharply, and formation uplifting occurred in the south, but the elevation was still lower than north. Now the structural amplitude in the south has surpassed that in the north, and two structural highs were formed where the south is higher than the north (Fig. 5e).

\section{Accumulation factors}

\subsection{Reservoir}

\subsubsection{Sequence stratigraphy and reservoir characteristics}

The Sarvak is a carbonate formation which deposited in a gently sloping shallow marine environment mostly during 
the Cenomanian to early Turonian (96-92) Ma (Murris 1980; Alsharhan and Nairn 1997). According to the highresolution sequence stratigraphy (Xu et al. 2007), six significant sedimentary cycles were distinguished. Moreover, 12 subzones were further distinguished based on well logging and paleontology. The oil intervals primarily include the Sar-8 in SEQ-4 and the Sar-3, 4, 5, 6 in SEQ-5. Sar- 1 and Sar- 2 zones are the regional dense interlayers of marl, mudstone, and shale, and the Sar-7 is mud/wackestone containing poor oil (Fig. 6).

The Sarvak is mainly a pore-type reservoir without large-scale high-angle tectonic fractures. Diagenetic microfissures and stylolites can be found in the cores but only densely distributed in a few parts. Vertically, the lithology and physical properties of various subzones are different and have strong heterogeneity. The lithology of the Sar-3 and Sar- 8 zones is mainly characterized by rudist grain/packstones which were deposited in high-energy sites (Fig. 7a). Karstification and in situ solution brecciation developed extensively during exposure of the upper sequences (Fig. $7 \mathrm{~g}$ ), while the pore types are mainly intergranular dissolved pores, moldic pores, and vugs (Fig. 7b, c). The porosity and permeability are, respectively, $15 \%-$ $35 \%$ and $10-150 \times 10^{-3} \mu \mathrm{m}^{2}$. The Sar-3 subzone has an average porosity of $17.7 \%$ and permeability of $45.5 \times 10^{-3} \mu \mathrm{m}^{2}$, and the average porosity and permeability of the Sar- 8 are $17.1 \%$ and $11.7 \times 10^{-3} \mu \mathrm{m}^{2}$, respectively. The Sar-4, 5, 6 subzones present a similar lithology of mainly two types: the foraminifera and mollusk packstone/wackestone of moderate-energy shallowwater deposition (Fig. 7d) with porosity and permeability of $10 \%-20 \%$ and 1 to $10 \times 10^{-3} \mu \mathrm{m}^{2}$, respectively (Fig. 8), as well as the planktonic foraminifera, echinoderm, and algae wackestone of low-energy deep-water deposition (Fig. 7f), and the porosity and permeability are $5 \%-15 \%$ and $0.1-5 \times 10^{-3} \mu \mathrm{m}^{2}$, respectively (Fig. 8). Pore types are mainly isolated intra-particle, residual intergranular pores, lime mud matrix, and moldic pores (Fig. 7e). The reservoir qualities of the Sar-4, 5, 6 are controlled by the depositional environment and are poorer than those of the Sar-3, 8, and the strong reservoir heterogeneity also causes relatively poor oiliness (Fig. $7 \mathrm{~h}$ ). The average porosity is $10.8 \%$, and the permeability is $3.8 \times 10^{-3} \mu \mathrm{m}^{2}$.

\subsubsection{Reservoir distribution}

The distribution of the upper Cretaceous rudist buildups in the Iraq-Iran border area is mainly controlled by the paleohighs which were generated by the Alpine tectonic activity (Alsharhan 1995; Glennie 2000; Sadooni and Aqrawi 2000; Sadooni 2005; Du et al. 2015b). During the growth of the rudist reef, when it reached the wave base when sea level fell, the rudist sand was formed from the reef by strong current erosion. After being transported and re-deposited, a gentle hilly, paleo-high centered and continuous rudist biostratum composed of rudist clastic grain/pack/wackestone was formed (Aqrawi et al. 1998; Sadooni 2005; Du et al. 2015b). So the Sar-3 and Sar-8 rudist-bearing layers are continuous with weak heterogeneity and thinning from north to south controlled by the paleo-high (Fig. 9a). The Sar-4, 5, 6 were mainly deposited in an open platform and lagoon environment where the sediments are predominantly from in situ deposition (Ghabeishavi et al. 2010), while the reservoir quality is mainly controlled by the depositional site. The shallower the water environment is, the better the reservoir quality is. According to the reservoir correlation, the Sar- $4,5,6$ are relatively better in the northern paleo-high; conversely, with the deposition setting turning deeper, in the southern paleo-low, the shale content is increasing, and the dense limestone is thickening, and the reservoir quality is showing a degradation trend from north to south. In general, the Sarvak reservoir is a massive and interconnected heterogenetic reservoir. Vertically, the subzones with diverse lithology and properties are connected to each other without clear boundaries and are interbedded. Laterally, the reservoir quality is mainly controlled by the paleo-geomorphology and shows the degrading trend from north to south, and this is also shown by the new 3D seismic interpretation (Fig. 9b).

\subsection{Source}

The source bed of the Sarvak reservoir in the Azadegan oil field has not been confirmed due to the lack of regional exploration. The regional resource studies mainly focus on the late Jurassic and early Cretaceous beds (Bordenave and Burwood 1990, 1995; Bordenave and Huc 1995; Bordenave and Hegre 2005). As for Sarvak, the potential sources are the Cretaceous Garau and Kazhdumi Formations (Fig. 2).

The Garau is composed of a series of thick carbonate muds, argillaceous limestones, and organic matter formed during the early Cretaceous Valanginian stage. It is believed that the Garau reached the oil window at the end of the Paleocene to early Miocene (Bordenave and Burwood 1990; Bordenave and Hegre 2005) and covered the whole Dezful Embayment in Iran. It is assumed, however, without faults or large-scale vertical fractures, the hydrocarbon from the Garau cannot cross the Kazhdumi dense bed with high pore pressure, and hence, it cannot migrate to the Sarvak (Alavi 1982; Bordenave and Hegre 2005). The large difference of the gravity of the crude oil between the Sarvak and lower reservoirs in Azadegan also indicates they have a different source (Fig. 10). The Kazhdumi Formation, deposited at the Cretaceous Albian stage, 


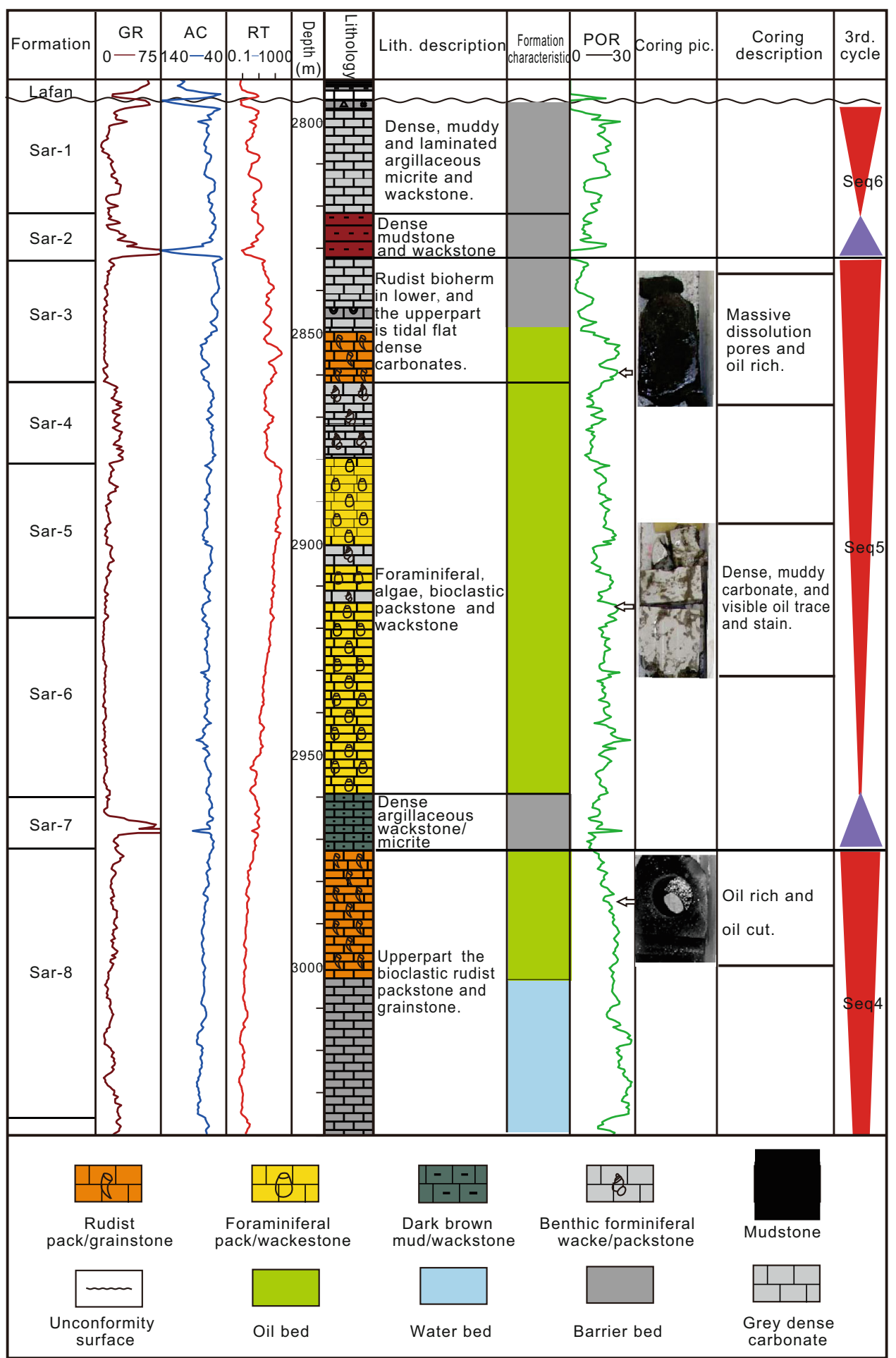

Fig. 6 Synthesized stratigraphic sequence histogram of the upper Sarvak in the Azadegan oil field

conformably contacts with the Sarvak (Murris 1980; Alsharhan and Nairn 1997; Bordenave and Burwood 1995; Bordenave and Huc 1995; Bordenave and Hegre 2005). Deep marine still water mudstone deposited in the central part of Dezful Embayment has an excellent hydrocarbon generation potential and is the main source rock for the traps in the Zagros foreland basin (Murris 1980; Bordenave and Burwood 1990, 1995; Bordenave and Huc 1995; 

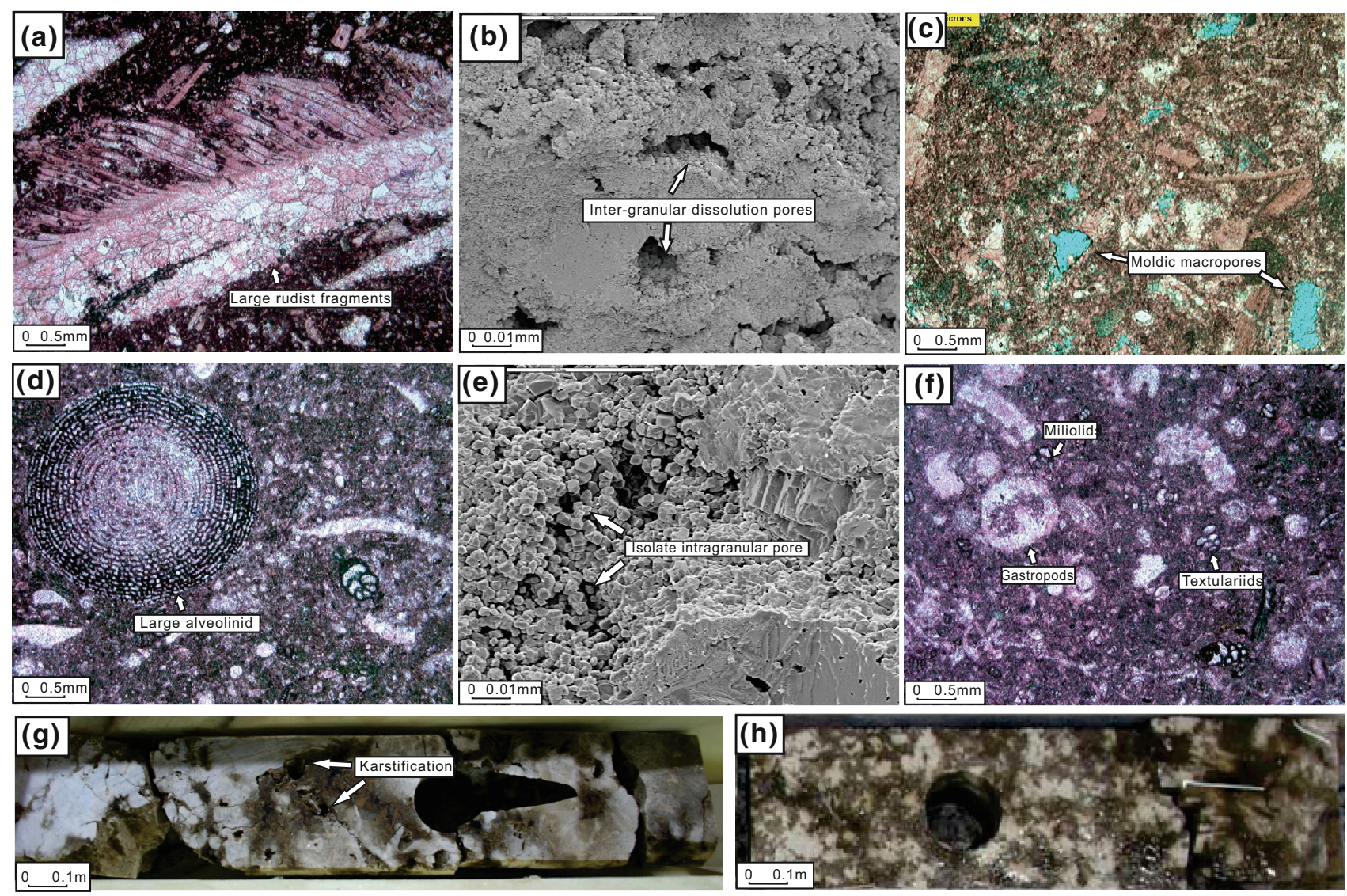

Fig. 7 The thin sections and SEM pictures of different subzones of Sarvak in the Azadegan oil field. a Sar-3, bioclastic packstone/wackestone containing rudist fragments. The large rudist fragment in the picture was originally bimineralic, consisting of calcite (upper part, microstructure well preserved) and aragonite (lower part, now blocky calcite spar); b Sar-3, SEM picture, macro-porosity comprises both primary inter- and intra-granular pores and secondary grain dissolution pores; c Sar-3, moldic macro-pores after leaching and dissolution of skeletal aragonite; d Sar-4, bioclastic/peloidal packstone containing large alveolinid foraminifera; e Sar-4, SEM picture, detailed view showing coarse blocky calcite cementing pores, and isolated micro-pores within the lime mud matrix; f Sar-5, bioclastic packstone containing gastropods, benthonic foraminifera (including textulariids and miliolids), and a variety of other skeletal grains; $\mathbf{g}$ Sar-3, core picture, the development of karstification, and in situ solution indicate the subaerial exposure of top of the Sar-3 subzone; $\mathbf{h}$ Sar-6, core, oil stain, and patch; the shallow color indicates the dense limestone and poor oiliness, and the dark color shows the zone with relatively good properties and oiliness

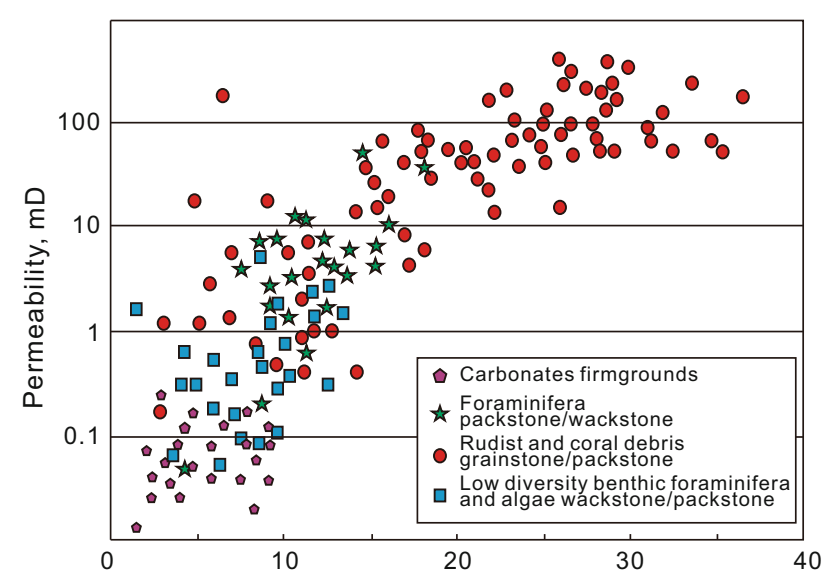

Fig. 8 The physical property cross-plot of coring in Sarvak with different lithologies
Bordenave and Hegre 2005; Zhang et al. 2012; Soleimani 2013). In the Azadegan oil field, dark brown and gray Kazhdumi marls were deposited without hydrocarbon potential. Regionally, the field is located in the western Dezful Embayment and far from the hydrocarbon generation center (Fig. 11).

The Japanese company Inpex collected crude oil $\mathrm{API}^{\circ}$ data from fields in the Iranian Dezful Embayment and Iraqi Mesopotamian Basin (Fig. 10, and the fields' locations are shown in Figs. 1 and 11). After comparing and analyzing, it is considered that the Sarvak in Azadegan has the same source as the eastern Ab-e Teymur oil field due to their similar oil properties (Fig. 10). The accumulation process is interpreted as follows: when the Kazhdumi of Ab-e Teymur became mature at 5-1 Ma (Bordenave and Hegre 2005), the oil charged the Zagros trend traps near the 

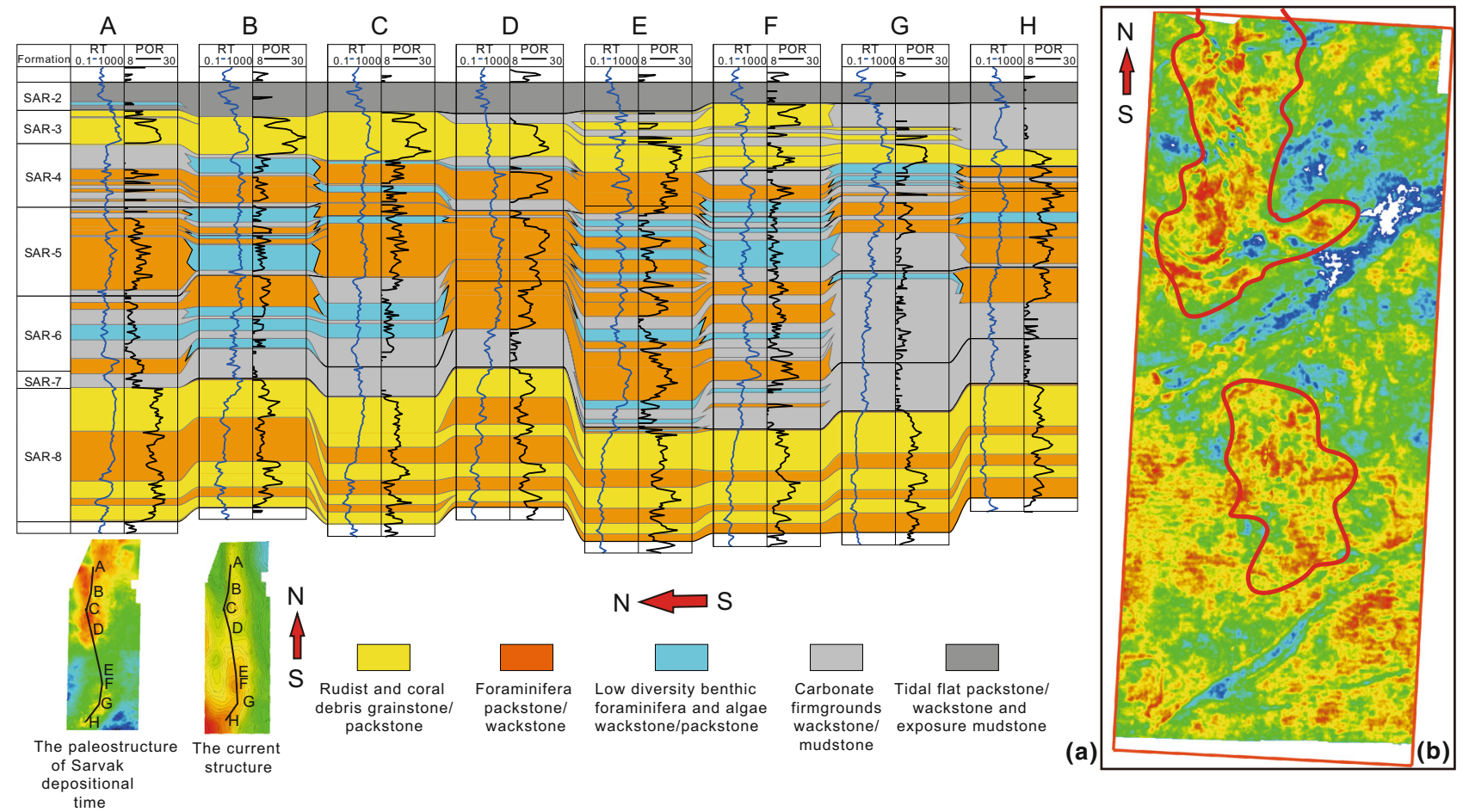

Fig. 9 The reservoir correlation figure of Sarvak in Azadegan field, Iran (a); the reservoir distribution prediction figure of South Azadegan oil field by newly 3-D seismic data; the red circle indicates the favorable reservoir zone (b)

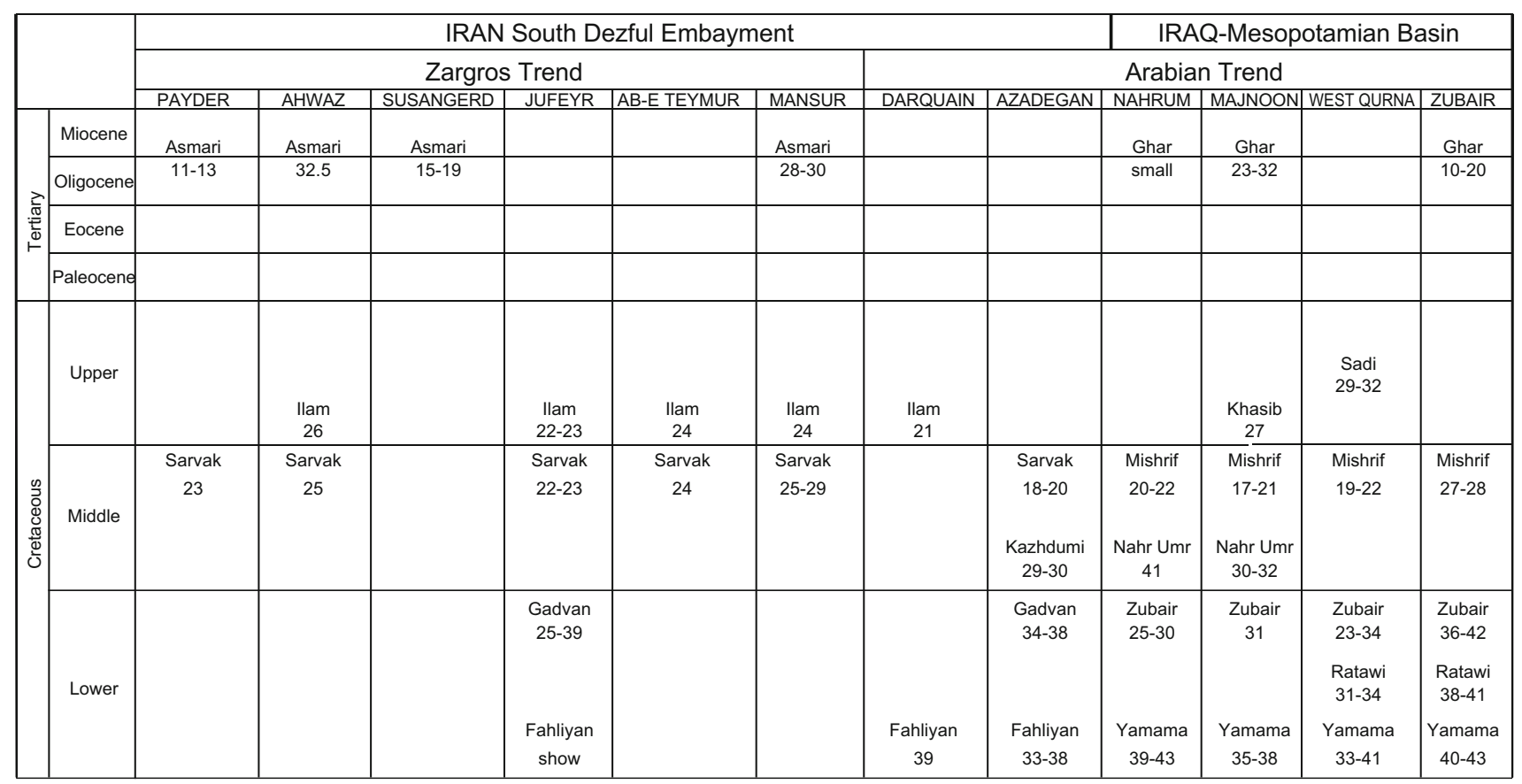

Fig. 10 Oil gravity of the oil fields from the Cretaceous to Miocene in the Dezful Embayment (unit: API ${ }^{\circ}$ )

generation center such as the Ab-e Teymur and Mansuri fields. After that, the oil charged the Arabian trend traps in the westwards basin margin like Azadegan by lateral migration. However, another two doubts need to be considered. Firstly, according to the findings of Bordenave and Burwood (1990, 1995) and Bordenave and Hegre (2005), 


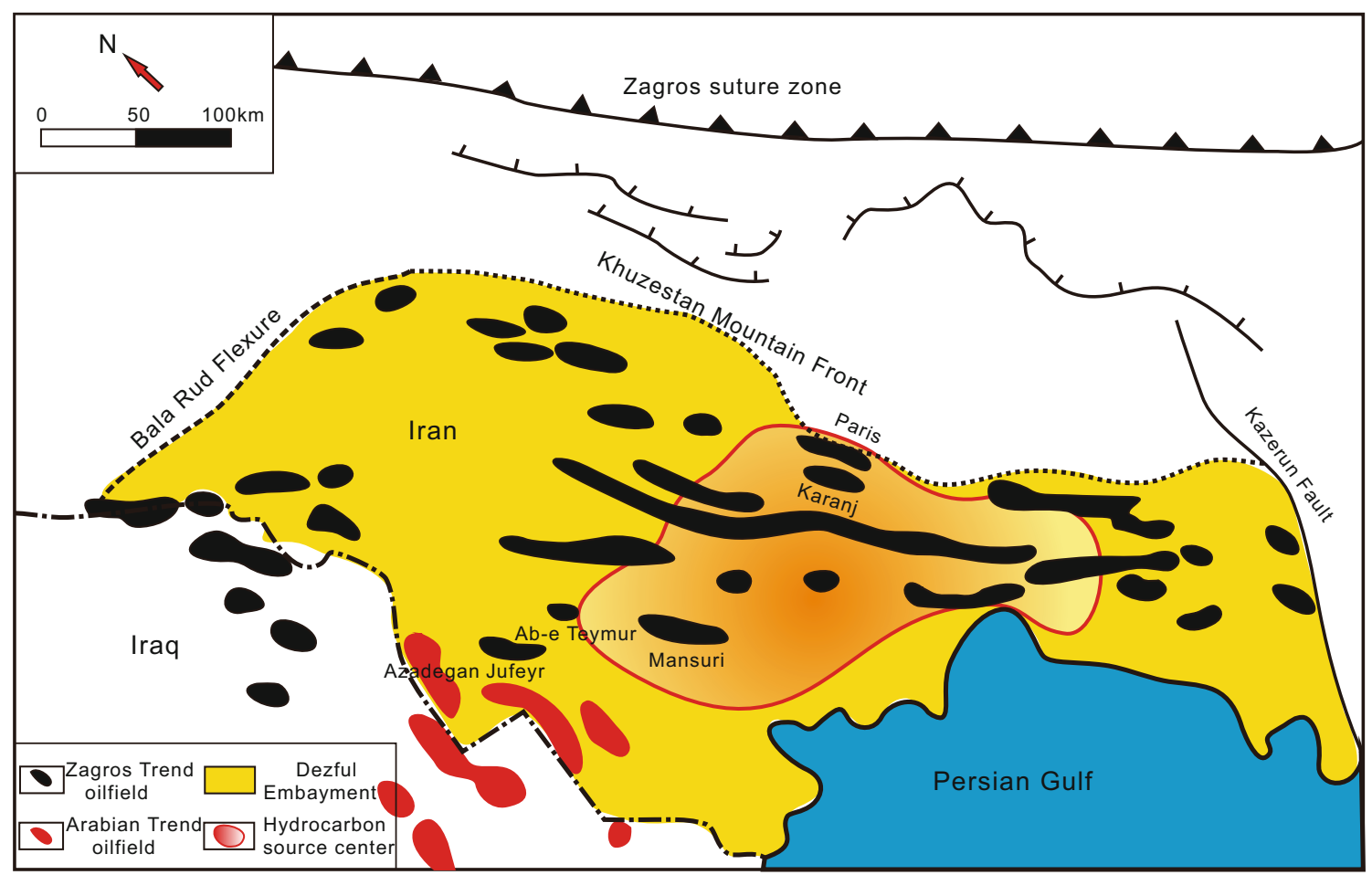

Fig. 11 Isopach map of source rock maturation in the Kazhdumi Formation (Bordenave and Hegre 2005)

most oil from Kazhdumi will first charge the nearby Zagros trend traps in Dezful Embayment. Assuming that the longrange lateral migration charging the Arabian trend traps will occur later, and according to the principal that the higher the source rock maturity is, the lower the crude oil gravity is, so the higher $\mathrm{API}^{\circ}$ of crude oil should be present in Arabian trend oil fields. Nevertheless, the data show that the crude oil gravity in both the Azadegan and the other Arabian trend traps are lower than that in the Zagros trend traps (Fig. 10), contrary to that assumption. Moreover, the filling of the Sarvak reservoir in the Jufeyr field of the eastern of Azadegan is only partial. Thus, it is hard to explain how the oil crosses the Jufeyr during the migration and directly infills the Azadegan (Fig. 11).

Bordenave and Hegre (2005) has discussed the relative timing and chronology of oil expulsion from the Kazhdumi and the formation of the Zagros trap in the Dezful Embayment, and concluded that both hydrocarbon generation peak periods of Kazhdumi and Zagros trap formation stage happened during the period 3-8 Ma, showing a compatible matching relation. Therefore, close range migration is dominant in the Dezful Embayment. However, some studies (Bordenave and Hegre 2005) also proved that parts of the Kazhdumi in the Dezful Embayment also reached the oil window and the expulsion stage commenced before $10 \mathrm{Ma}$ due to the rapid subsidence caused by the early folding, like the Karanj and Paris oil field areas (Fig. 11), which is earlier than the formation time of the
Zagros trend trap. Consequently, during that period, there were only Arabian trend traps in the west of Dezful Embayment, and the Zagros trend trap was not formed; nevertheless, parts of Kazhdumi source bed reached the oil window, and the low-maturity heavy crude oil was expelled and migrated long distances along the gently dipping ramps or the unconformity surface towards the western Arabian platform (Zagros Basin margin), charging the Arabian trend traps first. Afterwards, the source bed reached its peak time of hydrocarbon generation, while the Zagros traps were formed simultaneously. Thereafter, a short-range migration to the nearby Zagros trend traps took place. That is a valid explanation why the oil properties of Sarvak reservoir of Arabian trend traps show low $\mathrm{API}^{\circ}$, while Zagros trend traps have relatively low oil gravity with high source bed maturity.

\subsection{Seal}

In the Dezful Embayment of southwestern Iran, there are two favorable seal beds in the Cretaceous to Tertiary oil system, the Miocene Gachsaran which consists of salt and anhydrite rock as well as the Cenozoic Gurpi and Pebdeh consisting of marl, shale, and marly limestone (Fig. 2). Due to the fracturing caused by the strong tectonic compression, the seal efficiency of Gurpi and Pebdeh Formations in Zagros trend trap is limited and lowered, while the Cretaceous and Miocene reservoirs are connected by high- 
angle fractures and transformed into an unified reservoir whose main cap formation is the Gachsaran (McQuillan 1973, 1974; Alavi 1982; Wang et al. 2011; Zhang et al. 2012; Bordenave and Hegre 2005).

The Azadegan oil field is located in the transitional zone between the Arabian platform and Zagros foreland basin, which is relatively far away from the Zagros suture zone. Although the Zagros orogeny caused deformation of the subsurface layers, the shale and marl seals of Cenozoic formation (Gurpi and Pebdeh) did not develop intense fracturing due to the tectonic stress decreasing, yet still play a sealing role restraining vertical oil migration and dissipation (Bordenave and Hegre 2005). Logging interpretation and testing results show that the Miocene Asmari reservoir has good properties but only contains water, indicating that no vertical oil migration or charging from lower source beds occurred in the Azadegan. In addition, the Ilam of Azadegan, unlike the adjacent oil fields, is a dense marl and chalk limestone formation. With the Laffan shale formation and the Cenozoic formation described before, they all form an effective seal for Sarvak accumulation.

\section{Genesis of Sarvak unsteady reservoir}

Through combining the characteristics of the reservoir, source, seal, and the trap evolution, the Sarvak accumulation genesis and evolution are discussed.

The Sarvak Formation was deposited in the middle of the Cretaceous and evolved into the N-S Arabian trend anticline trap under the impact of Alpine tectonic activity and remained in a relatively stable state in the geological history from 65 to $20 \mathrm{Ma}$ (Fig. 12a, b). The Zagros orogeny commenced about $20 \mathrm{Ma}$, and when the Zagros trend fold had not been completely formed (before about 20-8 Ma), parts of the Kazhdumi source bed of the Dezful Embayment reached the oil window and expelled lowmaturity heavy crude oil. This charged the Arabian trend trap in the western Dezful Embayment by long-range migration and turned the Azadegan into a paleo-anticline accumulation (Fig. 12c). At approximate 3-4 Ma, the Zagros orogeny began impacting the Azadegan zone (margin area of the Zagros foreland basin) and led to the drastic secondary deformation of the paleo-trap. The paleotrap shrank dramatically, while the previously low southern formation was uplifted and formed a new secondary anticline trap. This evolutionary trend lasted till the present and is now evolving into the current structures of two domes with the south higher than the north.

Tectonic activity altered the paleo-reservoir trap shape and broke the reservoir kinetic equilibrium. The Gurpi and Pebdeh Formation seal beds prevented vertical dissipation, causing intra-formational secondary re-migration and adjustment in the Sarvak. The impact factors are as follows: (1) trap deformation and secondary migration proceeding simultaneously; (2) a massive reservoir with strong vertical and lateral heterogeneity; (3) heavy crude oil of high viscosity (18-20 API ${ }^{\circ}$; and (4) reservoir quality that shows a degradation trend from north to south (along the migration path). All of these mentioned above make the accumulation adjustment proceeding at a very slow rate and lag behind the trap deformation (Fig. 12d, e).

Based on the homogeneous reservoir secondary migration model (Fig. 13) and the corresponding oil/gas equilibrium formula below ( $\mathrm{Li} 2010$ ), the time needed for reaching the secondary reservoir equilibrium is calculated:

$t=\frac{\phi \mu_{0} \Delta L}{2 K \Delta \rho_{\mathrm{wo}} g \sin \alpha} \ln \frac{\tan \theta_{0}}{\tan \theta} \approx \frac{\phi \mu_{0} \Delta L}{2 K \Delta \rho_{\mathrm{wo}} g \sin \alpha} \ln \frac{\theta_{0}}{\theta}$,

where $\mu_{0}$ is the crude oil viscosity, $\mathrm{mPa} s ; K$ is the formation permeability, $\mathrm{mD} ; \Delta \rho_{\mathrm{wo}}$ is the density difference of water and oil, $\mathrm{g} / \mathrm{cm}^{3} ; \theta_{0}$ is the initial dip angle of the oilwater contact; and $\theta$ is the equilibrium dip angle of the oilwater contact.

The computed result is $1.78 \mathrm{Ma}$ for the Sar-3 and 10.86 Ma for the Sar 4-6. It should be noted that this is a rough static time length estimate based on the current structure condition and the reservoir properties are the average values from the core data. The calculation does not consider impacting factors such as the geologic synchronicity of the oil migration and trap deformation, and the strong reservoir heterogeneity. Otherwise, the time needed would be longer. The secondary trap deformation occurred after the formation of the surface Zagros trend fold (approx. $4 \mathrm{Ma}$ ), and the greater part of the re-migration occurred at an ultra-late stage. This is because the uplift of the southern secondary trap surpassed the northern paleo-trap at least after $2 \mathrm{Ma}$, and the higher elevation of the secondary trap would improve the upward buoyancy of the oil migration. The Sarvak reservoir could only experience a very short readjustment time span (perhaps only 1-2 Ma) less than the timeframe needed for the new reservoir equilibrium.

From the oil migration theory, during the migration process, the light component of crude oil will migrate first, and the heavy content will remain in the reservoir ( $\mathrm{Li}$ 2004). The PVT analysis also proved that the fluid properties are diverse in different zones in the field (Liu et al. $2013 b$ ). From north to south (paleo-trap to secondary trap), the density is lighter and the viscosity becomes lower, which means the fluid mobility is getting better from north to south, and it also proves the reservoir is still in the remigration process from the reservoir engineering standpoint (Fig. 14). 


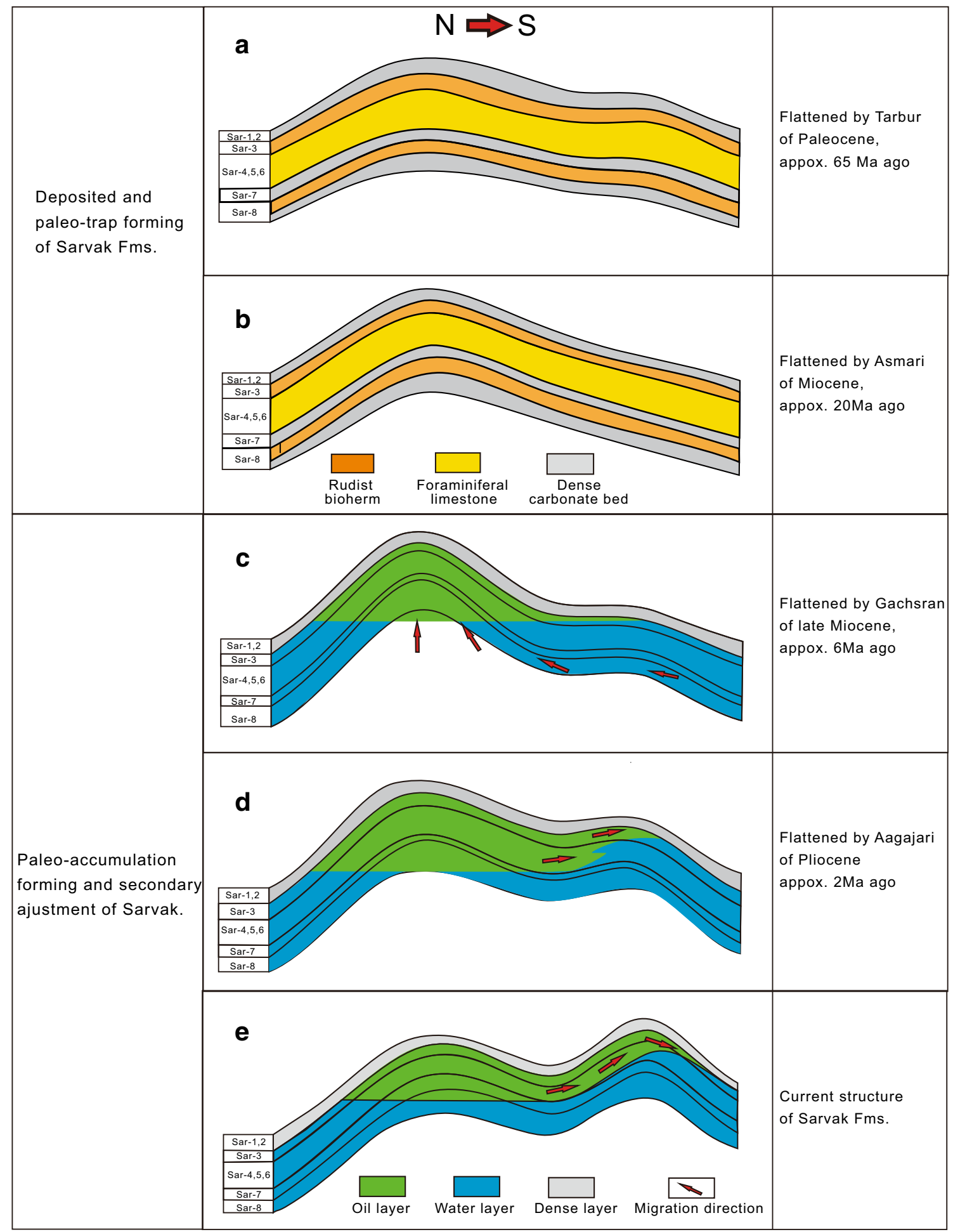

Fig. 12 Sketch map of Sarvak reservoir evolution of the Azadegan oil field in different geological stages (the accumulation evolution corresponds with the trap evolution of Fig. 5)

To sum up, the strong reservoir heterogeneity makes the secondary adjustment occur at a very low rate, while the very late trap deformation does not provide the time required, so these two main factors together caused the
Sarvak reservoir to form an unsteady reservoir which has not reached a new equilibrium and is currently in an unstable process of re-migration, accumulation, and adjustment. The nearly stable horizontal OWC of the 


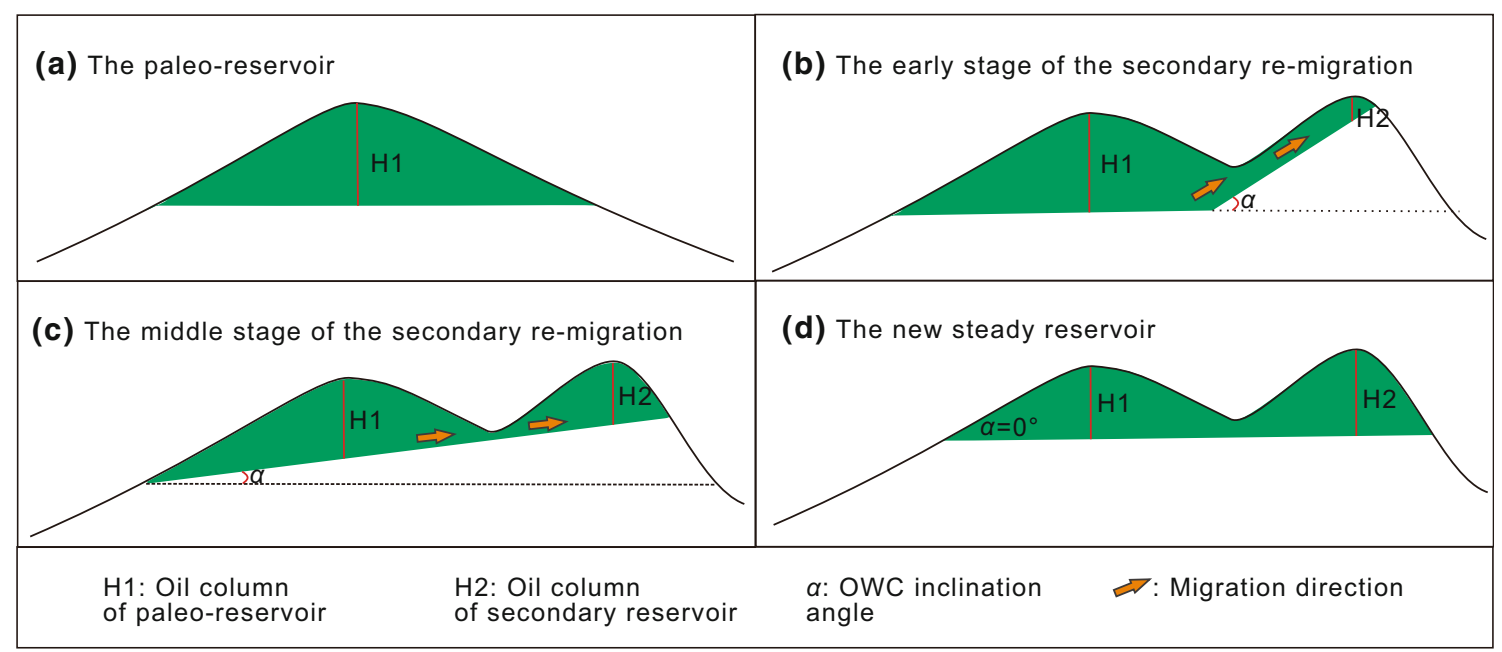

Fig. 13 A schematic figure of the secondary migration and adjustment process in the homogeneous reservoir model. This model ignores the formation time interval of the secondary trap. Generally, the reservoir adjustment can be described as the oil column decreasing in the paleoreservoir and increasing in the secondary reservoir, along with a decreasing of the OWC inclination angle

northern crest wells (these wells are in the paleo-reservoir area) indicates that the current reservoir is still in the early stage of the secondary re-migration and has no impact on the whole paleo-reservoir (Fig. 13b). This caused the primitive and stable horizontal OWC in the northern paleoreservoir and the highly tilted OWC in the southern secondary reservoir.

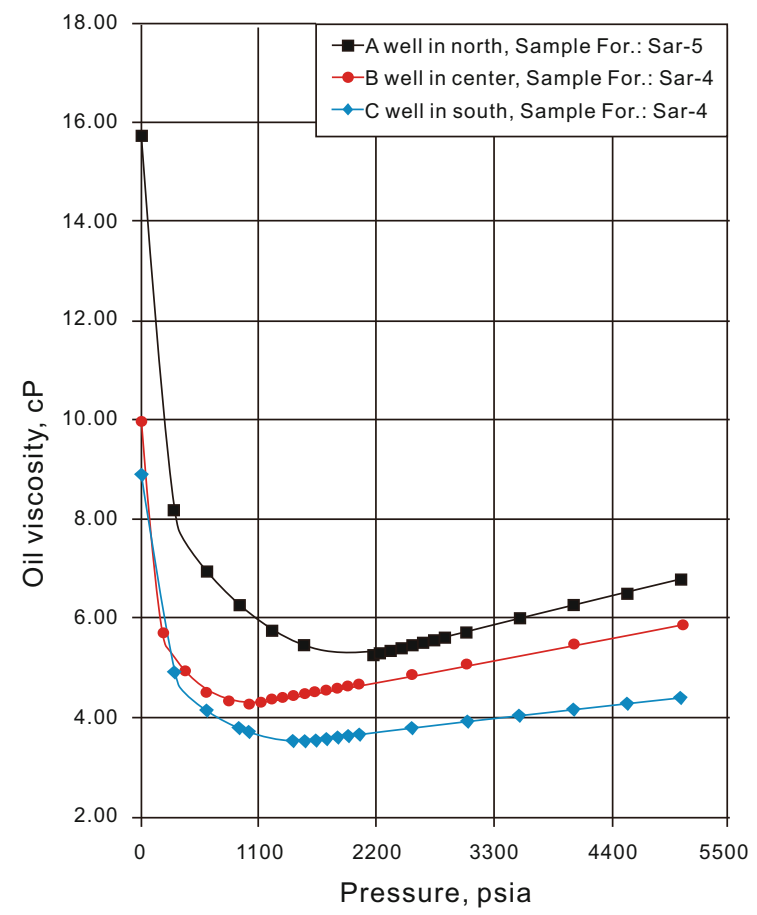

\section{Development suggestion}

The "unsteady reservoir" is a new type of reservoir that was proposed by Chinese scholars based on the exploration of an unconventional oil field in the Tarim Basin in the west of China and defined as a dynamically balancing oil entrapment which is still in the process of charging or

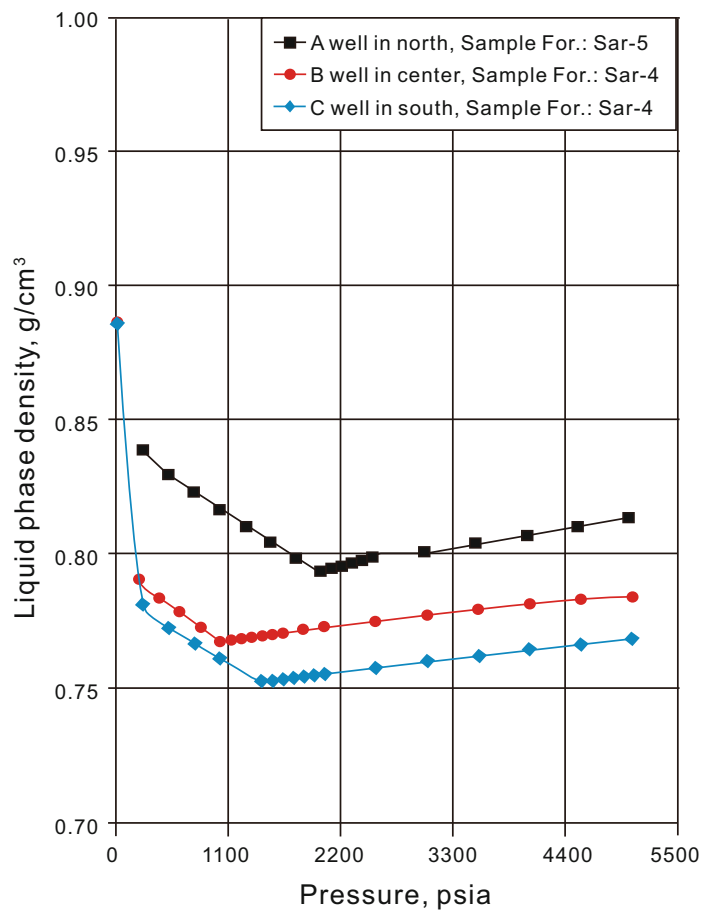

Fig. 14 Sketch map of PVT analysis in Sarvak (the well locations of A, B, C are shown in Fig. 4b) 


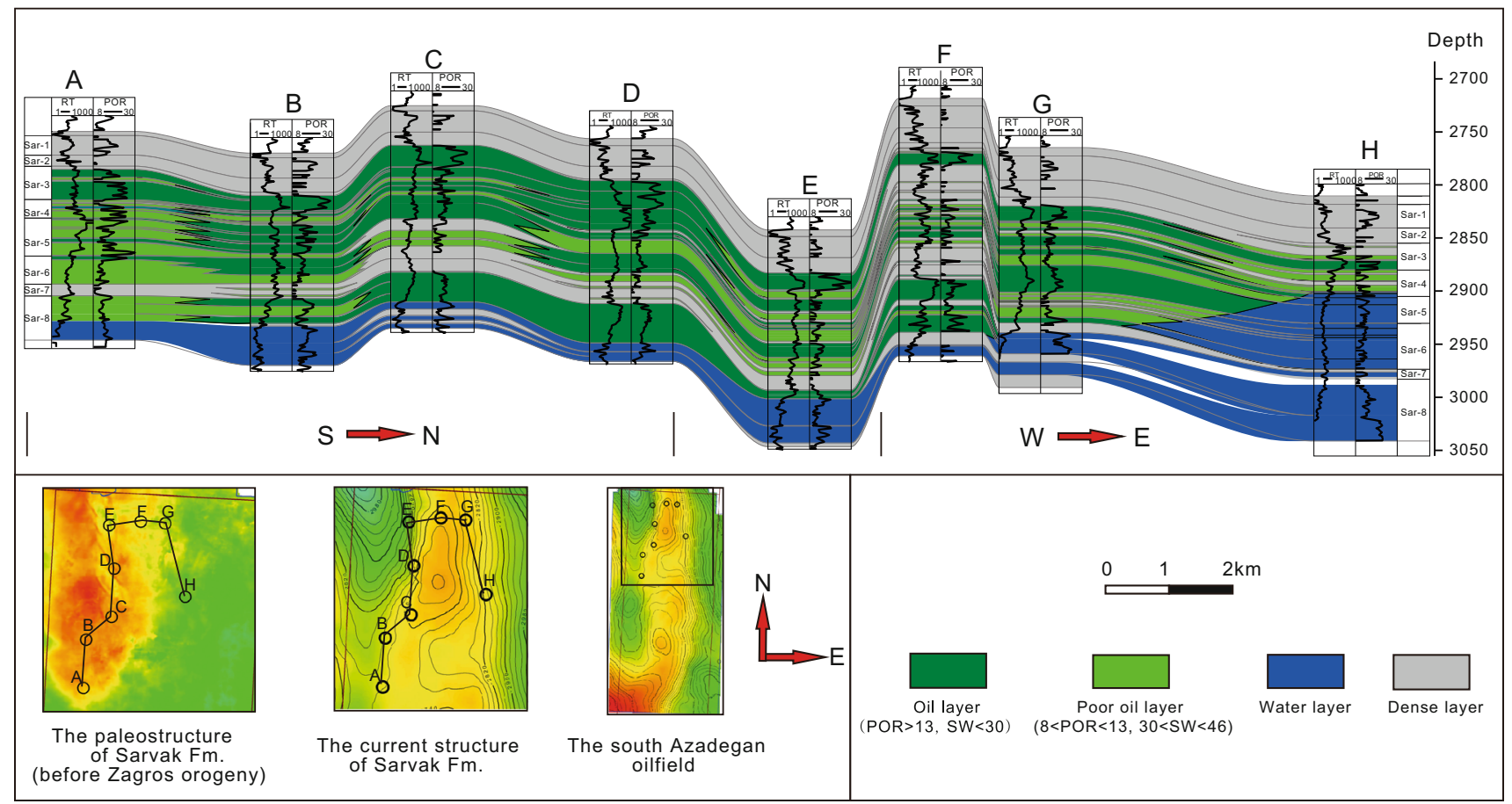

Fig. 15 The reservoir section of the northern high in the South Azadegan oil field

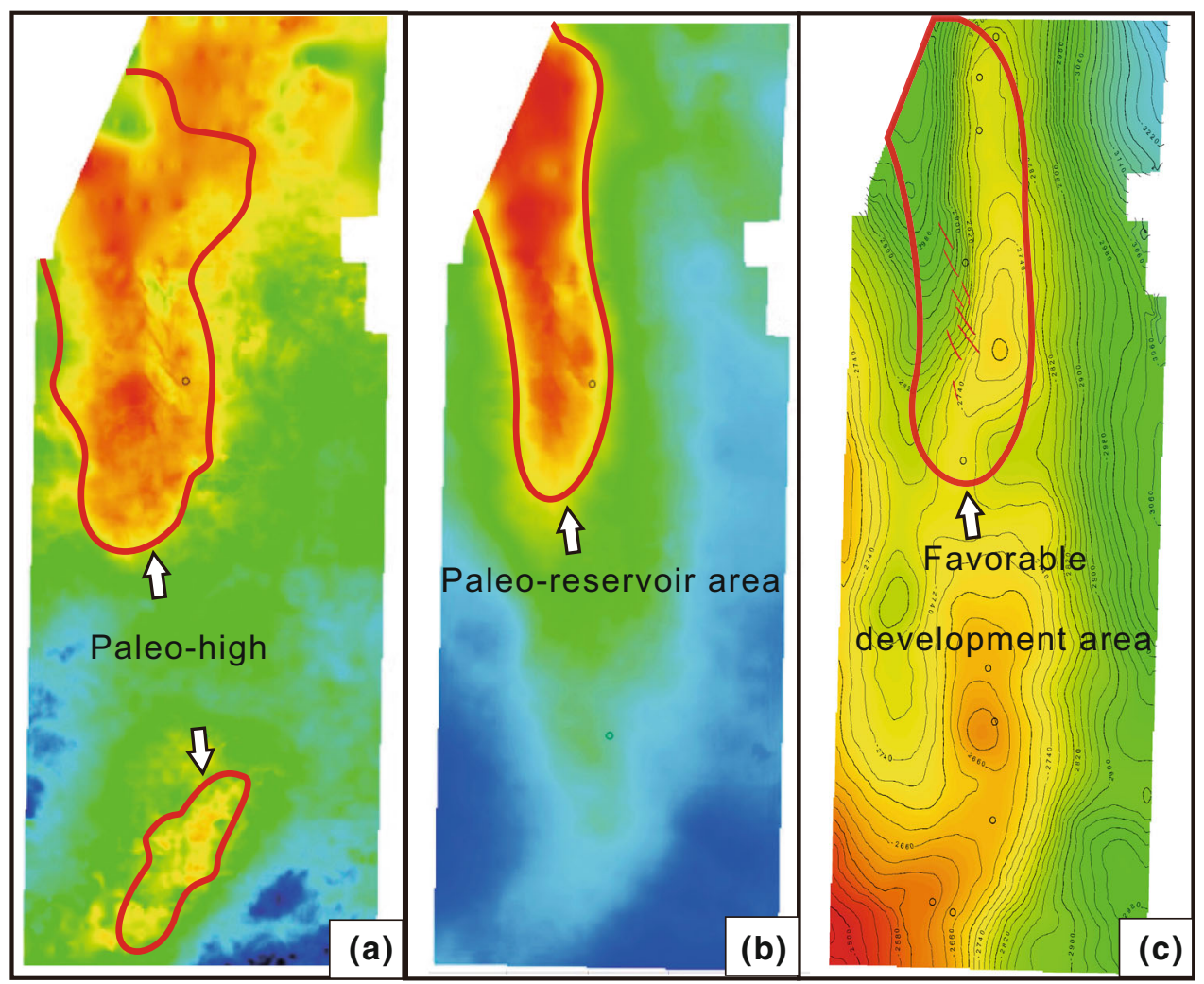

Fig. 16 Sketch map of the development suggestion for the Azadegan oil field. a The paleo-geomorphology of the depositional stage of the Sarvak; b The paleo-reservoir plane distribution of the Sarvak; $\mathbf{c}$ the favorable development area in the current structure 


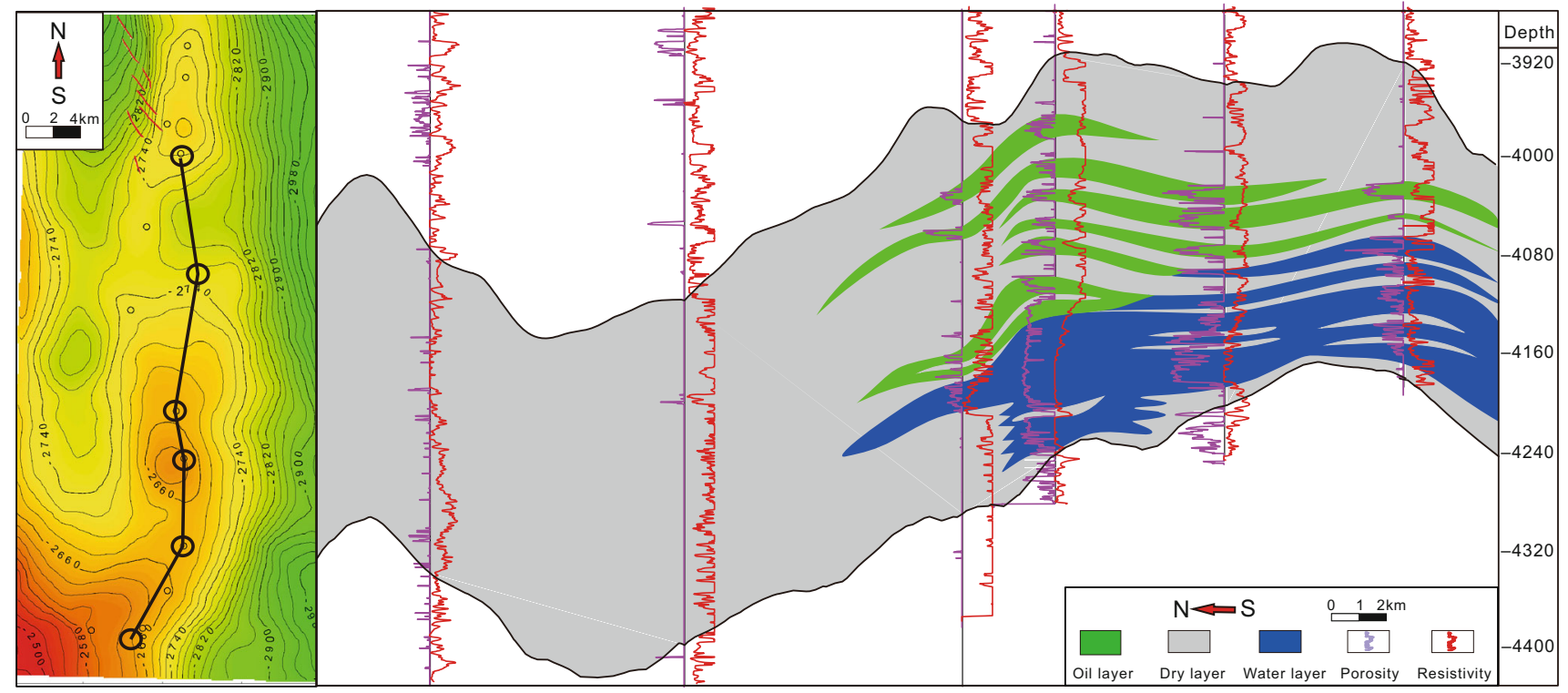

Fig. 17 Reservoir section of the lower Cretaceous Fahliyan Formation in the Azadegan oil field (N-S), Iran

adjusting by hydrocarbon migration as well as from structural activity and evolution, while the reservoir adjustment follows the trap adjustment (Sun et al. 2008, 2009; Jiang et al. 2008; Xu et al. 2008; Yang et al. 2012). According to this theory, the Sarvak reservoir of the Azadegan oil field belongs to the "charging type unsteady reservoir," and it can be divided into the retention reservoir which is a "paleo-reservoir" (the north high) and the "presecondary reservoir" which is still in the process of migration and accumulation in the secondary trap (the south high) (Yang et al. 2012). It has been noted that the Sarvak reservoir is still in the early readjustment phase, and the paleo-reservoir did not cause the integral re-migration. Therefore, the current northern high (the location of the paleo-reservoir) should be in its original state and not controlled by the current structure. Based on this, five wells were drilled in the west flank of the northern high in the south Azadegan field (Fig. 15). Results indicate all of these wells show a stable horizontal OWC and thicker oil columns relative to the structure position. Thereafter, the $\mathrm{H}$ well located in the east flank (paleo-low) proves that the tilted OWC also exists in the E-W trend along the minor axis. From the above, the northern high is the most favorable development zone due to both the good reservoir properties of the paleo-high and the paleo-reservoir situation (Fig. 16). Additionally, contrary to the conventional theory, the wells should not be drilled along the crest of structure but ought to be in the paleo-reservoir trap zone in the west flank of the current northern high (Fig. 16). Meanwhile, oil pay thickness which could be impacted by the tilted OWC should be considered as well in reserve calculations.
The southern high is the secondary trap formed by the Zagros activity in the very late stage, while the secondary reservoir is still in the process of re-migration. Regarding the southern reservoir, the pinching out of the reservoir thickness of the Sar-3 and the weaker reservoir quality of the Sar-4, 5, 6 is caused by the lower paleo-geography. Moreover, the decreasing oil pay thickness is caused by the higher OWC. Thus, the southern secondary reservoir is not the priority development zone. On the contrary, the authors have shown that the Kazhdumi (Burgan sandstone) and Gadwan (Zubair sandstone) reservoirs have formed a completed secondary reservoir in the new southern trap due to the good reservoir connectivity, reservoir quality, and low oil viscosity (Du et al. 2015c). Based on that, we can develop the southern lower sandstone reservoir first, while collecting more geological data of the upper Sarvak and then optimizing the development by using the static and dynamic data such as the 3D seismic and production dynamic analysis of the existing wells.

The lower Cretaceous Fahliyan reservoir is a matrix pore-type carbonate reservoir of which lithology is oolitic limestone and the average porosity/permeability is $19.6 \% /$ $12.7 \times 10^{-3} \mu \mathrm{m}^{2}$, similar to the Sarvak. Based on the good tectonic inheritance of the Cretaceous formation and the same trap evolution trend in Azadegan field, it is assumed that the Fahliyan reservoir should possess the same unsteady characteristics. The newly drilled wells proved the prediction and showed a tilted OWC with around $120 \mathrm{~m}$ height difference north to south in the reservoir. Hence, it is an unsteady lithological-structural reservoir (Fig. 17). Therefore, the development method should follow the Sarvak example that confirms the favorable 
development zone by analyzing the reservoir distribution and paleo-reservoir location.

\section{Conclusions}

The genesis of the Sarvak unsteady reservoir in Azadegan oil field can be generalized as follows: the paleo-trap of the Sarvak formed at an early geological stage (after the upper Cretaceous) and the paleo-reservoir formed at a later geological stage (after the middle Miocene). The secondary reservoir adjustment caused by tectonic activity occurred at an ultra-late stage (after the Pliocene). The characteristics of the Sarvak reservoir are those of a massive carbonate reservoir with strong heterogeneity both vertically and laterally, and reservoir quality degrades along the secondary migration path, with a very short readjustment time span and high-viscosity crude oil. These factors together result in reservoir readjustment at a very slow rate and insufficient secondary readjustment. This has ultimately formed the unsteady reservoir with the irregular tilted OWC.

The "unsteady reservoir" is a new concept proposed by Chinese scholars in recent years. The relevant theory concerning this kind of reservoir has been successfully trialed in some Chinese oil fields, proving its objectivity and validity. It is believed that in the transition zone between the Arabian Platform and Zagros foreland basin, there should have been a greater number of oil fields similar to Azadegan oil field. Thorough analysis and identification of this kind of reservoir is highly recommended. It is also believed, based on this research, that the unsteady reservoir theory with relevant development methods has much scope for improvement and broad prospects of application in the Middle East.

Open Access This article is distributed under the terms of the Creative Commons Attribution 4.0 International License (http://crea tivecommons.org/licenses/by/4.0/), which permits unrestricted use, distribution, and reproduction in any medium, provided you give appropriate credit to the original author(s) and the source, provide a link to the Creative Commons license, and indicate if changes were made.

\section{References}

Alsharhan AS, Nairn AEM. Sedimentary basins and petroleum geology of the middle east. Amsterdam: Elsevier; 1997. p. 813-43.

Alsharhan AS. Facies variations, diagenesis and exploration potential of the Cretaceous rudist-bearing carbonates of the Arabian Gulf. AAPG Bull. 1995;79(4):531-50.

Aqrawi AAM, Thehni GA, Sherwanni GH, et al. Mid-Cretaceous rudist-bearing carbonates of the Mishrif Formation: an important reservoir sequence in the Mesopotamian Basin, Iraq. J Pet Geol. 1998;21(1):57-82.

Alavi M. Chronology of trap formation and migration of hydrocarbons in Zagros sector of South West Iran. AAPG Bull. 1982;66(10):1535-41.

Alavi M. Tectonics of the Zagros orogenic belt of Iran, new data and interpretations. Tectonophysics. 1994;229(3-4):211-38.

Alavi M. Regional stratigraphy of the Zagros fold-thrust belt of Iran and its proforeland evolution. Am J Sci. 2004;304(1):1-20.

Berberian M, King GCP. Towards a paleogeography and tectonic evolution of Iran. Can J Earth Sci. 1981;18(2):210-65.

Beydoun ZR. Arabian plate hydrocarbon geology and potential-a plate tectonic approach, AAPG Stud Geol. 1991. p. 33-77.

Bordenave ML, Burwood R. Source rock distribution and maturation in the Zagros belt: provenance of the Asmari and Bangestan reservoir oil accumulations. Org Geochem. 1990;16(1):369-87.

Bordenave ML, Burwood R. The Albian Kazhdumi Formation of the Dezful Embayment, Iran: one of the most efficient petroleum generating systems. Petroleum Source Rocks. Heidelberg: Springer; 1995. p. 183-207.

Bordenave ML, Huc AY. The Cretaceous source rocks in the Zagros Foothills of Iran. Oil Gas Sci Technol. 1995;50(6):727-52.

Bordenave ML, Hegre JA. The influence of tectonics on the entrapment of oil in the Dezful embayment, Zagros fold belt. Iran. Pet Geol. 2005;28(4):339-68.

Colman SP. Fold development in Zagros simply folded belt, Southwest Iran. AAPG Bull. 1978;62(6):984-1003.

Du Y, Yi YJ, Xin J, et al. Genesis of large-amplitude tilting oil-water contact in Sarvak Formation in South Azadegan Oilfield, Iran. Pet Geol Exp. 2015a;37(2):187-93 (in Chinese).

$\mathrm{Du}$ Y, Xin J, Xu QC, et al. The rudist buildup depositional model based on reservoir architecture: a case from the Sarvak reservoir of the SA oilfield, Iran. Acta Sedimentol Sin. 2015b;33(6):1247-57 (in Chinese).

$\mathrm{Du}$ Y, Xin J, Chen J, et al. Review on the characteristic of Kazhdumi reservoir in SA Oilfield, Iran. J Southwest Pet Univ (Sci Technol Ed). 2015c;37(6):30-8 (in Chinese).

Gussow WC. Differential entrapment of oil and gas: a fundamental principle. AAPG Bull. 1954;38(5):816-53.

Ghabeishavi A, Vaziri MH, Taheri A, et al. Microfacies and depositional environment of the Cenomanian of the Bangestan anticline, SW Iran. Asian Earth Sci. 2010;37(3):275-85.

Glennie KW. Cretaceous tectonic evolution of Arabia's eastern plate margin: a tale of two oceans. Middle east models of Jurassic/ Cretaceous Carbonate systems. SEPM Spec Publ. 2000;69:9-20.

Hessami K, Koyi HA, Talnot CJ, et al. Progressive unconformities within an evolving foreland fold-thrust belt, Zagros Mountains. J Geol Soc Lond. 2001;158(6):969-81.

Jiang TW, Xu HL, Lian ZG, et al. Origin of tilted oil-water contact and probe into the theory of unsteady hydrocarbon accumulation. J Southwest Pet Univ (Sci Technol Ed). 2008;30(5):1-6 (in Chinese).

Koop WJ, Kholief MM. Subsidence history of the Middle East Zagros Basin. Philos Trans R Soc Lond Ser A. 1982;305:149-67.

Li CL. Theoretical analysis of dipping water-oil contacts (II). Xinjiang Pet Geol. 2010;30(5):653-4 (in Chinese).

Li MC. Basic principles of migration and hydrocarbon exploration. Earth Sci-J China Univ Geosci. 2004;29(4):379-83 (in Chinese).

Liu H, Guo R, Dong JC, et al. Productivity evaluation and influential factor analysis for Sarvak reservoir in South Azadegan oil field, Iran. Pet Explor Dev. 2013a;40(5):585-90.

Liu Z, Tian CB, Zhang WM, et al. Causes of hydrodynamic pressure distribution: a case of the 4th Pay in Zubair Formation, Rumaila Oilfield, Iraq. Pet Explor Dev. 2013b;40(6):774-9. 
McQuillan H. Small-scale fracture density in Asmari Formation of southwest Iran and its relation to bed thickness and structural setting. AAPG Bull. 1973;57(12):2367-85.

McQuillan H. Fracture patterns on Kuh-e Asmari anticline, southwest Iran. AAPG Bull. 1974;58(2):236-46.

Murris RJ. Middle East: stratigraphic evolution and oil habitat. AAPG Bull. 1980;64:587-618.

Sadooni FN, Aqrawi AAM. Cretaceous sequence stratigraphy and petroleum potential of the Mesopotamian basin Iraq. SEPM Spec Publ. 2000. p. 315-34.

Sadooni FN. The nature and origin of Upper Cretaceous basin margin rudist buildups of the Mesopotamian Basin, southern Iraq, with consideration of possible hydrocarbon stratigraphic entrapment. Cretac Res. 2005;26(2):213-24.

Sepehr M, Cosgrove JW. Structural framework of the Zagros foldthrust belt, Iran. Mar Pet Geol. 2004;21(7):829-43.

Sherkati S, Letouzeh J. Variation of structural style and basin evolution in the Central Zagros (Izeh zone and Dezful Embayment) Iran. Mar Pet Geol. 2004;21(5):535-54.

Schowalter TT. Mechanics of secondary hydrocarbon migration and entrapment. AAPG Bull. 1979;63(5):723-60.

Stöcklin J. Structural history and tectonics of Iran. AAPG Bull. 1968;52(7):1229-58.

Soleimani M. Simulation of petroleum exploration based on a conceptual decision model: taking the Dezful Embayment in southwestern Iran as an example. Pet Explor Dev. 2013;40(4):476-80.
Sun LD, Jiang TW, Xu HL, et al. Exploration and practice for theory of unsteady-state hydrocarbon accumulation. Mar Origin Pet Geol. 2008;13(3):11-6 (in Chinese).

Sun LD, Jiang TW, Xu HL, et al. Unsteady reservoir in Hadson Oilfield, Tarim Basin. Pet Explor Dev. 2009;36(1):62-7 (in Chinese).

$\mathrm{Xu}$ DJ, Zhang WC, Du XJ, et al. Reservoir characteristics and development suggestion of chalky limestone in the Zagros Basin, Iran. Pet Geol Exp. 2010;32(1):15-8 (in Chinese).

Xu HL, Jiang TW, Gu QY, et al. Probe into hydrocarbon accumulations in the Hadson oilfield, Tarim Basin. J Southwest Pet Univ (Sci Technol Ed). 2008;30(5):17-21 (in Chinese).

Xu GQ, Zhang SN, Li ZD, et al. Carbonate sequence stratigraphy of a back-arc basin: a case study of the Qom Formation in the Kashan Area, Central Iran. Acta Geol Sin. 2007;81(3):488-500.

Wang Q, Cheng XB, Zhang WB. Approach to hydrocarbon accumulation in piedmont of Zagros foreland basin, Iran. Xinjiang Pet Geol. 2011;32(2):204-6 (in Chinese).

Yang HJ, Sun LD, Zhu GY, et al. Characters and formation mechanism of unsteady reservoirs in Tarim Basin. Acta Pet Sin. 2012;33(6):1103-11 (in Chinese).

Zhang Z, Li HW, Duan HZ, et al. Geological characteristics and hydrocarbon accumulation model of the Cenozoic Asmari Gachsran play, Zagros Basin. Oil Gas Geol. 2012;33(2):190-7 (in Chinese). 